\title{
The Study on Evaluation Module Architecture of ERP for Chemical Enterprises
}

\author{
Yongbin Qin ${ }^{1,2, a}$, Jiayin Wei ${ }^{1, b}$ \\ ${ }^{1}$ College of Computer Science and Information, Guizhou University, Guiyang, 550025, China \\ ${ }^{2}$ Postdoctoral Workstation, Chitianhua Group Company, Guiyang, 550001, China \\ aemail: ybqin@foxmail.com, bemail: weijiayin05@sina.com
}

Keywords: Assessment and Evaluation; ERP; Evaluation Module; Evaluation Indicators

\begin{abstract}
Good assessment and evaluation of ERP is very important for us to know the effect of implement ERP. In this paper, we bring forward evaluation module architecture of chemical enterprises ERP based the actual situation of some chemical enterprise. Enterprises can make comprehensive assessment and evaluation of ERP through the module including six evaluation indicators.
\end{abstract}

\section{Introduction}

The ERP system is the core of enterprise informatization construction. The original intention of enterprise ERP is to change the traditional management model. With informatization as the carrier, promoting the management efficiency of enterprises, enhancing the management level and competitiveness and then enterprises can gain greater benefits.

Before the ERP is put into practice, we usually need to do systemic analysis and investigation for the current situation of enterprise. So, we can set up the overall objectives and quantitative objectives of actualizing ERP in order to make sure that we can carry out comprehensive assessment and evaluation after the ERP system is deployed formally. We should make sure that the deployment of the ERP is a benefit rather than a burden. For a company, any input should generate returns. Otherwise, the interests of company will be damaged and the implementation of ERP will lose its significance. So, for a company, what and how many returns do enterprises get from the implementation of ERP, it is the most concerned problem for enterprise decision makers. The input of enterprise ERP system is a long-term process. The input includes hardware costs, software costs, maintenance costs and training costs of internal staff, especially maintenance costs and training costs of internal staff are a long process. The implementation of ERP relates to all aspects of the company. Thus, it is a systemic and complex work to evaluate the performance of some enterprises. This is very important for enterprise decision makers to implement ERP firmly.

So, how to evaluate the performance plays a critical role in promoting enterprise informatization construction. Promoting the application performance effectively requires enterprises to carry out regular assessment and evaluation for performance of ERP in or after the process of the implementation of enterprises ERP. The aim of objective and scientific analysis of the ERP performance is facing the problems and solving them. So then we can strengthen the subject awareness of enterprises and enhance enforcement and application. Through qualitative analysis, quantitative calculation and objective and fair evaluation, we can reveal the performance of ERP from different standpoints scientifically. This is good for the application of ERP in enterprises and then the success rate of ERP can be raised enough.

This paper studies on the chemical enterprises of Guizhou, combining with the situation of enterprises and performance of ERP, we bring forward a new evaluation module of chemical enterprises ERP. This module concentrates on enhancing efficiency and interests of enterprises.

\section{The Situation Analysis of ERP Assessment and Evaluation}

The study of assessment and evaluation method of the ERP is concentrated on the work 
achievement and effectiveness after the ERP is put into effect. The purpose of the assessment and evaluation is based on objective and strategy of the implementation of ERP and examines the effect of the administration and management. The main purpose of ERP assessment and evaluation is lying in some points as follows. 1) The enterprises can fully understand progress and status of the implementation of ERP through the assessment and evaluation; 2) Through comparing with the objectives and standards set before implementation, we can find the effect and shortage of the implementation of the ERP, and then improve and deepen the implementation of the ERP.

The assessment and evaluation of the ERP system is system engineering. Since the emergence of ERP system, many scientific researchers do a systematic study on the assessment and evaluation methods. For example, the America scholars, Delone and McLean bring forward a success model of information system in 1992 [1][2]. The model is called D\&M model. The D\&M model is based on the analysis of 180 papers about successfully measuring information systems and summarizes six main dimensions about success of information system. The six main dimensions are system quality, information quality, system using, user satisfaction, personal influence and organizational influence. System quality measures stabilization, response time and usability of system itself. Information quality measures effectiveness, timeliness and accuracy of the information generated by the system. System using measures the time and frequency of using system, the number of using information and the system dependence. User satisfaction can be governor satisfaction or overall satisfaction. Because of strong operability, satisfaction is a measure of the most widely used. Personal influence includes strengthening the efficiency of decision-making managers. Organizational influence includes the improvement of financial indicators, such as the enhancing of sales amount, market share, the market value of shares and profit margin, the reducing of the cost, capital turnover time and inventory, the improvement of the production efficiency, the service efficiency and the products quality, or the maintaining and strengthening of the strategic competitive advantage.

The D\&M model regards the success of information system as a process that includes time relationship and causality. The information system should be established and implemented first, its feature is reflected in the system quality and information quality. Users know about the characteristics of information system through using systems and then get the judgment of satisfaction about system. So, system quality and information quality affect system using and user satisfaction jointly and separately. System using and user satisfaction affect personal influence directly and ultimately affect organizational performance. D\&M model regards the information system as a multi-dimensional variable. We could not say that a dependent variable is better than another one. We should choose the dependent variable which will be investigated based on the research objectives, the organizational environment, the concrete study aspect of system, independent variables, research method and level of analysis. At the same time, they also believe that conducting the research from a comprehensive perspective is necessary.

Markus et al. bring forward that the success of ERP is a multi-dimensional, dynamic, and relative concept [3]. In order to solve the multi-dimensional, dynamic, and relative problem of the successful estimate of system, Markus et al. bring forward a new most ideal successful framework of ERP, that is stage theory of ERP assessment and evaluation. The stage theory describes the best results of implementing ERP in certain business conditions. The framework measures the success of ERP system from the following three aspects.

1) Project Metrics: the success of ERP system is that the system completes the installation in the scope of time, budget and plan. The success assessment and evaluation of this metrics is similar to the assessment and evaluation of traditional project management.

2) Early Operational Metrics: Markus regards that the ERP systems may be a little chaos and reducing of performance at the beginning as a result of the complexity of ERP and maladjustment to the new systems. The initial operation stage is from the online of the ERP system to returning to normal operating level of the original. In this stage, the success of the system includes little fluctuation of key performance indicators, quickly reaching the normal or expected level, few influences to the enterprise and the customers.

3) Long-term Business Interests: it means that the ERP system has been working and the 
enterprises get commercial interests from the implementation of ERP system. The success of this metrics is that the enterprises get how many and what business interests from the implement of ERP system. The assessment and evaluation of long-term business interests should compare with the objective of enterprise or the expectation of ERP. Markus regards that the objective of one single enterprise may be slighter than the huge potential ability of ERP. So, the good idea is to compare the average benefits of the implement of ERP of similar enterprises with the commercial interests of our enterprises.

Shang and Seddon bring forward a comprehensive commercial interests framework of ERP through analyzing 233 ERP applications [4]. They regard that the implementation of ERP will have an impact on the business interests of enterprises. It can bring about interests of five aspects such as operation, management, strategy, IT and organization. So the enterprise can evaluate the success of the implement of ERP from the aspects of implementation of commercial interests. These five aspects can be divided into different interest framework and then form a relatively complete assessment framework of interests.

Some academicians did some special research work on financial performance after the implementation of ERP and got some research results [5][6][7][8][9][10].

For the assessment and evaluation of the implementation of ERP, many enterprises do not have clear evaluation criteria. We do not have a scientific and clear evaluation criteria on how to accurately and comprehensive evaluate effectiveness of implementation of ERP project. Some experts and scholars in the United States bring forward a lot of standards and methods to evaluate performance of ERP. Although these methods are used widely, these methods are concerned about the process of the implementation of ERP, such as what to do, whether or not be done, normalization and accuracy, the function of ERP software, they hardly concentrate on the content of the effect after the implementation of ERP or how to do quantitative evaluation. And these evaluation criteria have not become international standard, so we should do some intensive and wide discussion and research about assessment and evaluation of ERP. This helps to doing scientific assessment and evaluation of ERP, further improving the ERP project evaluation and acceptance specification, well understanding the features and functions, effectively improving the application level of ERP and the management level of enterprises. If we want to carry out the assessment and evaluation of the enterprises ERP, we should know about the actual situation of ERP and establish reasonable standard of assessment and evaluation.

The traditional assessment and evaluation of ERP based on function could not be fully applicable to the assessment and evaluation of ERP. The reasons of it are as follows.

1) The traditional pattern of assessment and evaluation originates from financial results. There is a certain lag of it. It cannot reflect the dynamic business operation.

2) The traditional assessment and evaluation is only for the relevant functional departments but could not evaluate operation flow.

3) The traditional method could not make real-time assessment and evaluation for the business processes. While it focus on ex post analysis.

\section{Principles of Setting Indicator System of Performance Evaluation for Chemical Enterprises}

The chemical enterprises, especially agricultural chemical, have unique business characteristics, for example, the supply of resources is relatively stable and single, marketing channel is relatively stable, they are typical resource-based enterprises. On account of these typical resource-based enterprises, combined with the actual situation of a chemical enterprise, we need establish the evaluation standard and model of ERP for the current enterprise. So, we think that the chemical enterprises should follow the following principles when setting indicator system.

1) Relevance principle: The performance evaluation index can reflect the strategic target of enterprise and can serve the strategic objectives of enterprises.

2) Pertinence principle: Many enterprises are emphasized in comprehensive assessment and evaluation of ERP, which is comprehensive evaluation. However, according to characteristics of chemical enterprises and different requirements of different enterprises, we should set indicator 
system of performance evaluation for chemical enterprises with pertinence.

3) Core principle: Maybe enterprises concentrate on many different evaluation indicators, but the managers of the enterprises may be concerned with only some core evaluation indicators. So we should enhance the weight of the core evaluation indicators and strengthen the intention of the enterprises managers.

4) Operability principle: Enterprises should take the operability principle into account. Adhere to the principle of combining qualitative and quantitative, mainly using quantitative principle. Make sure that the evaluation indicators are feasible.

5) Deduction principle: The evaluation indicators should be forecasted. Enterprises can forecast the performance of enterprises after the implementation of ERP through deduction.

6) Relative stability principle: Once the enterprises set the standard of the assessment and evaluation, they should make sure the relative stability. The assessment and evaluation is effective and comparable over a period of time.

\section{Analysis of Evaluation Indicators for Assessment and Evaluation of Enterprises ERP}

Based on the analysis of the principle of assessment and evaluation for chemical enterprises ERP and the present status and features of some chemical enterprise of Guizhou, we bring forward the evaluation module architecture of chemical enterprise ERP which include six indicators. The six indicators are finance indicators, market indicators, resource indicators, efficiency indicators, customer indicators and human indicators. The six indicators are described as follows.

TABLE I. FINANCE INDICATORS

\begin{tabular}{|c|c|l|}
\hline \multirow{5}{*}{ Finance Indicators } & Clear accounts & $\begin{array}{l}\text { Overall informatization of finance, the accounts are clear and } \\
\text { visible. }\end{array}$ \\
\cline { 2 - 3 } & $\begin{array}{c}\text { Financial } \\
\text { efficiency }\end{array}$ & Whether or not the efficiency of accounting accounts is enhanced. \\
\cline { 2 - 3 } & Stock level & The total assets of the enterprise, sales revenue, total profit. \\
\cline { 2 - 3 } & $\begin{array}{c}\text { Enterprise } \\
\text { income }\end{array}$ & $\begin{array}{l}\text { Rate of return on Net assets of enterprise, rate of return on total } \\
\text { assets. }\end{array}$ \\
\cline { 2 - 3 } & $\begin{array}{l}\text { Operation ability } \\
\text { Capital turnover, inventory cycle rate, turnover rate of fixed } \\
\text { assets. }\end{array}$ \\
\cline { 2 - 3 } & $\begin{array}{c}\text { Fund utilization } \\
\text { rate }\end{array}$ & Enterprise funds utilization rate. \\
\hline
\end{tabular}

TABLE II. MARKET INDICATORS

\begin{tabular}{|c|c|l|}
\hline \multirow{4}{*}{ Market indicators } & Goods supply & Whether or not the supply of goods is secure and timely. \\
\cline { 2 - 3 } & $\begin{array}{c}\text { Capital recovery } \\
\text { rate }\end{array}$ & Customer payments after the goods are sold. \\
\cline { 2 - 3 } & Market share & Whether or not market share is increasing. \\
\cline { 2 - 3 } & $\begin{array}{c}\text { Development } \\
\text { ability }\end{array}$ & $\begin{array}{l}\text { Growth rate of sales revenue, total assets growth rate, growth rate } \\
\text { of profit, capital accumulation rate. }\end{array}$ \\
\hline
\end{tabular}

TABLE III. RESOURCE INDICATORS

\begin{tabular}{|l|c|l|}
\hline \multirow{2}{*}{$\begin{array}{l}\text { Resource } \\
\text { indicators }\end{array}$} & Resources supply & $\begin{array}{l}\text { Whether or not the supply of production resources meet the needs } \\
\text { of production. }\end{array}$ \\
\cline { 2 - 3 } & $\begin{array}{l}\text { Resource } \\
\text { inventory }\end{array}$ & $\begin{array}{l}\text { The inventory of enterprise production resources and goods } \\
\text { inventory. }\end{array}$ \\
\hline
\end{tabular}

\section{TABLE IV. EFFICIENCY INDICATORS}

\begin{tabular}{|l|l|l|}
\hline \multirow{5}{*}{$\begin{array}{l}\text { Efficiency } \\
\text { indicators }\end{array}$} & $\begin{array}{l}\text { Managerial } \\
\text { effectiveness }\end{array}$ & $\begin{array}{l}\text { To enhance the efficiency of the administrative management of the } \\
\text { enterprise. }\end{array}$ \\
\cline { 2 - 3 } & $\begin{array}{l}\text { Employee } \\
\text { productivity }\end{array}$ & $\begin{array}{l}\text { Whether or not the employee's work efficiency, production } \\
\text { efficiency and other indicators are promoted. }\end{array}$ \\
\cline { 2 - 3 } & $\begin{array}{l}\text { Business } \\
\text { efficiency }\end{array}$ & Market supply efficiency, customer efficiency. \\
\cline { 2 - 3 } & $\begin{array}{l}\text { Resources supply } \\
\text { efficiency }\end{array}$ & Timeliness for supply of resources of enterprise required. \\
\hline
\end{tabular}


TABLE V. CUSTOMER INDICATORS

\begin{tabular}{|l|l|l|}
\hline \multirow{4}{*}{$\begin{array}{l}\text { Customer } \\
\text { indicators }\end{array}$} & $\begin{array}{l}\text { Customer } \\
\text { satisfaction }\end{array}$ & Service satisfaction, product delivery rate. \\
\cline { 2 - 3 } & Market share & Market share, new customers. \\
\cline { 2 - 3 } & Customer loyalty & Customer stability, retention rate. \\
\cline { 2 - 3 } & $\begin{array}{l}\text { Customer } \\
\text { profitability }\end{array}$ & Profitability of customers. \\
\hline
\end{tabular}

TABLE VI. HUMAN INDICATORS

\begin{tabular}{|l|l|l|}
\hline \multirow{4}{*}{ Human indicators } & Labor cost & $\begin{array}{l}\text { The rate of staff training costs increasement over enterprise profit } \\
\text { increasement }\end{array}$ \\
\cline { 2 - 3 } & $\begin{array}{l}\text { Working } \\
\text { familiarity }\end{array}$ & The familiarity of using the ERP system for staffs. \\
\cline { 2 - 3 } & Staff motivation & Staffs work motivation, enthusiasm of using the new system. \\
\cline { 2 - 3 } & $\begin{array}{l}\text { Employee } \\
\text { benefits }\end{array}$ & The ratio of number of employees and enterprise profits. \\
\hline
\end{tabular}

\section{The Evaluation Module Architecture of ERP for Chemical Enterprises}

Based on the above evaluation indicators, we bring forward a new module of assessment and evaluation for chemical enterprises ERP. This module takes the increasing of the enterprise efficiency and benefits as the basic standard. We call it FMRRECH-module.

The evaluation formula is as follows.

$$
\sum=A^{*} Q_{1}+B^{*} Q_{2}+C^{*} Q_{3}+D^{*} Q_{4}+E^{*} Q_{5}+F^{*} Q_{6}
$$

Of which, A, B, C, D, E, F stands for finance indicators, market indicators, resource indicators, efficiency indicators, customer indicators and human indicators.

$Q_{1}+Q_{2}+Q_{3}+Q_{4}+Q_{5}+Q_{6}=1$

The value of $Q_{1}, Q_{2}, Q_{3}, Q_{4}, Q_{5}, Q_{6}$ can be set by the actual situation of the enterprise, we can adjust the weights of them.

The evaluation formula of $\mathrm{A}$ is: $\sum_{A_{i} \in\left\{A_{1}, A_{2}, \ldots\right\}} A_{i} * \alpha_{i}$

The evaluation formula of $\mathrm{B}$ is: $\sum_{B_{i} \in\left\{B_{1}, B_{2}, \cdots\right\}} B_{i} * \beta_{i}$

The evaluation formula of $\mathrm{C}$ is: $\sum_{C_{i} \in\left\{C_{1}, C_{2}, \cdots\right\}} C_{i} * \gamma_{i}$

The evaluation formula of D is: $\sum_{D_{i} \in\left\{D_{1}, D_{2}, \ldots\right\}} D_{i} * \delta_{i}$

The evaluation formula of $\mathrm{E}$ is: $\sum_{E_{i} \in\left\{E_{1}, E_{2}, \ldots\right\}} E_{i} * \lambda_{i}$

The evaluation formula of $\mathrm{F}$ is: $\sum_{F_{i} \in\left\{F_{1}, F_{2}, \cdots\right\}} F_{i} * \rho_{i}$

Taking finance indicators $A$ for example, according to table1, $A_{1}, A_{2}, A_{3}, A_{4}, A_{5}, A_{6}$ stand for clear accounts, financial efficiency, stock level, enterprise income, operation ability, fund utilization rate. The values of them are $15,20,15,20,15,15$, total of them is $100 . \alpha_{i}$ is the weight coefficient of FMRRECH-module. The standard of the weight coefficient is as follows.

TABLE VII. WEIGHT COEFFICIENT OF FMRRECH-MODULE

\begin{tabular}{|c|c|c|}
\hline Rank & Content description & Weight coefficient \\
\hline 1 & $\begin{array}{l}\text { Complete all the contents of the corresponding evaluation } \\
\text { indicators; }\end{array}$ & 1 \\
\hline 2 & Complete $80 \%$ of the contents; & 0.8 \\
\hline 3 & Complete $60 \%$ of the contents; & 0.6 \\
\hline 4 & Complete $40 \%$ of the contents; & 0.4 \\
\hline 5 & Complete $20 \%$ of the contents; & 0.2 \\
\hline 6 & Complete $10 \%$ of the contents; & 0.1 \\
\hline 7 & Complete $0 \%$ of the contents; & 0 \\
\hline 8 & Complete nothing of the contents; & -0.2 \\
\hline
\end{tabular}

The weight coefficient of table7 considers the positive offset and negative offset for the 
assessment and evaluation. We can set proper weight coefficient according to the actual situation of enterprises.

\section{Conclusion}

In this paper, based on the actual situation of chemical enterprises, we bring forward new evaluation module architecture of Chemical Enterprises ERP. This module takes the increasing of the enterprise efficiency and benefits as the basic standard. Enterprises can thoroughly evaluate the performance of ERP through six evaluation indicators.

\section{Acknowledgement}

We thank for the anonymous reviewers for their helpful comments and others for useful discussions. Thanks for the postdoctoral workstation of Chitianhua Group Company.

This paper is supported by the National Natural Science Foundation of China (NSFC, NO. 60863005; No.61262006), the Science and Technology Foundation of Guizhou Province (NO.20122125), the Scientific Research Project of Introduce Talents of Guizhou University (NO.201114) and the Foundation of Informatization of Manufacturing Industry of Guizhou Province (NO. GY (2011) 3074).

\section{References}

[1] Delone, W. H. , and Mclean, E. R. Information System Success: The Quest for the Dependent Variables, Information System Research [J], 1992.

[2] Xianghua Lu, Literature Review on Evaluation of Enterprise Information System Project, Science of Science and Management of S.\&.T. 2003, 24(2).

[3] Markus M.L., and Tanis C., The enterprise systems experience - from adoption to success, In R.W. Zmud(ed. ), Framing the Domains of IT Management: Projecting the Future Through the past. Cincinnati, OH: Pinnaflex, 2000.

[4] Shang S. and Seddon P.(2002), A Comprehensive Framework for Classifying the Benefits of ERP Systems, Americas Conference on Information Systems, Long beach, California, AUG,2000.

[5] McAfee A . , The Impact of Enterprise Resource Planning Systems on Company Performance[C], Paper presented at Wharton Electronic Supply Chain Conference Philadelphia, December 1999.

[6] Murphy K. E. and Simon S. J., Using Cost Benefit Analysis for Enterprise Resource Planning Project Evaluation: A Case for Including Intangibles[C], Proceedings of the 34th Hawaii International Conference on System Sciences, 2001.

[7] Poston R. and Grabski S., Financial Impacts of Enterprise Resource Planning Implementations, International Journal of Accounting Information Systems, 2001.2: 271-294.

[8] Hunton J. E. and Flower L., Information Technology in Accounting: Assessing the Impact on Accountants and organizations, In: Advances in Accounting Information Systems, S. C Sutton (ed. ), JAJ Press, Greenwich, CT, 1997: 3-34.

[9] Nicolaou A. I., Quality of Post Implementation review for Enterprise Resource Planning systems [J], International Journal of Accounting Information Systems, 2004.5: 25-49.

[10] Deloitte Consulting LLC. Deloitte Consulting' s Perspective: Making ERP spell ROI, ERP's Second Wave: Maximizing the Value of ERP-Enabled Processes[R], 1999: 17-23. 